\title{
POWER, POLITICS, AND PRINCIPLES
}

\author{
Mackenzie King and Labour, 1935-1948
}

Why have Canadian union density rates remained relatively stable, in sharp contrast to the decline in American unionization since the 1960s? Power, Politics, and Principles traces the root of this question back to the passing of PC 1003 in 1944, a wartime order that protected the right of workers to organize and form unions and forced employers to negotiate at the collective bargaining table. In detailing the significance of this pivotal labour law, author Taylor Hollander brings a new perspective to bear on its creator and proponent, William Lyon Mackenzie King. While many scholars have characterized the former prime minister as politically calculating and opportunistic, Hollander argues that Mackenzie King's adherence to key principles - particularly his determination to preserve and enhance the cohesiveness of the country - resulted in the creation of a more favourable legal environment for Canadian workers and their unions than that which existed across the border. Through secondary sources as well as a wide range of primary materials collected from government departments, wartime agencies, labour organizations, and corporate offices, Hollander delves into the policymaking process, revealing how the passing of this wartime order marked a new stage in Canadian industrial relations.

TAYLOR HOLLANDER is a middle school history teacher at Orchard House School in Richmond, Virginia. 
This page intentionally left blank 


\section{Power, Politics, and Principles}

Mackenzie King and Labour, 1935-1948

TAYLOR HOLLANDER

UNIVERSITY OF TORONTO PRESS

Toronto Buffalo London 
(C) University of Toronto Press 2018

Toronto Buffalo London

utorontopress.com

Printed in Canada

ISBN 978-1-4875-0234-8 (cloth)ＩSBN 978-1-4875-2193-6 (paper)

(®) Printed on acid-free, $100 \%$ post-consumer recycled paper with vegetablebased inks.

\section{Library and Archives Canada Cataloguing in Publication}

Hollander, Taylor, author

Power, politics, and principles : Mackenzie King and labour, 1935-1948 /

Taylor Hollander.

Includes bibliographical references and index.

ISBN 978-1-4875-0234-8 (hardcover). - ISBN 978-1-4875-2193-6 (softcover)

1. Labor policy - Canada - History - 20th century. 2. Labor laws and legislation - Canada - History - 20th century. 3. Labor unions - Canada History - 20th century. 4. Collective bargaining - Canada - History 20th century. 5. Canada - Politics and government-1935-1948. 6. King, William Lyon Mackenzie, 1874-1950. I. Title.

HD8106.H65 2018 331.097109’044 C2018-900444-4

University of Toronto Press acknowledges the financial assistance to its publishing program of the Canada Council for the Arts and the Ontario Arts Council, an agency of the Government of Ontario.

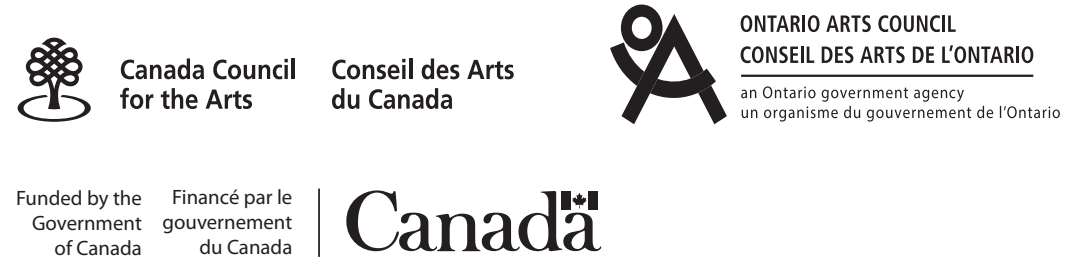

